\title{
Multiple Effects of Nitrogen Fertilization on Grape Vegetative Growth, Berry Quality and Pest Development in Mediterranean Vineyards
}

\author{
Arturo Cocco ${ }^{+} \mathbb{D}$, Luca Mercenaro ${ }^{*}+$, Enrico Muscas, Alessandra Mura, Giovanni Nieddu and Andrea Lentini $\mathbb{D}$ \\ Department of Agricultural Sciences, University of Sassari, Viale Italia 39, 07100 Sassari, Italy; \\ acocco@uniss.it (A.C.); muscas.enrico@gmail.com (E.M.); amura1@uniss.it (A.M.); gnieddu@uniss.it (G.N.); \\ lentini@uniss.it (A.L.) \\ * Correspondence: mercenar@uniss.it \\ t These authors have equally contributed to the manuscript.
}

check for updates

Citation: Cocco, A.; Mercenaro, L.; Muscas, E.; Mura, A.; Nieddu, G.; Lentini, A. Multiple Effects of Nitrogen Fertilization on Grape Vegetative Growth, Berry Quality and Pest Development in Mediterranean Vineyards. Horticulturae 2021, 7, 530. https://doi.org/10.3390/

horticulturae7120530

Academic Editor: Esmaeil Fallahi

Received: 21 October 2021

Accepted: 27 November 2021

Published: 29 November 2021

Publisher's Note: MDPI stays neutral with regard to jurisdictional claims in published maps and institutional affiliations.

Copyright: (c) 2021 by the authors. Licensee MDPI, Basel, Switzerland. This article is an open access article distributed under the terms and conditions of the Creative Commons Attribution (CC BY) license (https:// creativecommons.org/licenses/by/ $4.0 /)$.

\begin{abstract}
Nitrogen is a key macronutrient for the quantitative and qualitative yield of grapes; in addition, it influences the development and reproduction of grape pests. The multiple effects of different nitrogen rates were investigated on the red berry cultivar 'Carignano' and the grape pest Planococcus ficus in a two-year field trial. Different amounts of ammonium nitrate were compared: 0, 80 and 160 Units ha $^{-1}$ for mineral nitrogen. The amount of nitrogen fertilization supplied influenced the nitrogen status of vines and increased the pruning weight and leaf area, as well as the overall grape yield, by increasing the cluster weight. However, doubling the nitrogen rate did not generally increase the vegetative and productive parameters of grapevines. At harvest, nitrogen supply did not influence the anthocyanin content, tritatable acidity, and soluble solids, although the latter parameter showed a clear, yet not significant, decreasing trend. Planococcus ficus exhibited higher fecundity, survival and shorter development time on grapevines provided with nitrogen, whereas its fertility was unaffected by nitrogen fertilization. Ultimately, nitrogen had a direct and positive effect on grape yield and vine mealybug development, highlighting the importance of integrated cultural and pest control practices to promote grape production.
\end{abstract}

Keywords: Vitis vinifera; must chemical composition; nutrition; Planococcus ficus; vine mealybug; cultural control; VMB

\section{Introduction}

Soil fertilization is a cultural technique with a great impact on grape yield and quality of must and wine [1]. In this context, nitrogen (N) plays an essential role in grape growth, being the main compound for the development of shoot and leaf. The seasonal dynamics of $\mathrm{N}$ are well known and consist of its translocation from woody perennial to newly-formed organs from budburst to flowering. Starting from spring, roots absorb this macronutrient mainly in the nitrate form, reaching the maximum adsorption rate from bloom to fruit set [2], whereas its uptake decreases from veraison to leaf fall, when $\mathrm{N}$ stored in annual organs is reallocated to woody tissues [3].

Both $\mathrm{N}$ deficiency and excess may contribute to reducing yield and fruit quality. Mediterranean viticulture is traditionally carried out without irrigation, whereas nitrogen is usually applied, beginning in late winter, directly to the soil mostly as nitrate, ammonium, amide, or amino acid. It is well known that nitrogen requirements of grapevines are fairly low and are considered to be fewer than $100 \mathrm{~kg} \mathrm{ha}^{-1}$ during a crop cycle [4]. On the other hand, low nitrogen availability decreases the $\mathrm{N}$ content in berries, with a negative impact on the wine-making process [5], and reduces the aromatic quality and ageing potential of white wines [6]. Keller et al. [7], using pot-grown 'Cabernet Sauvignon' vines, reported that moderate nitrogen supplies before bloom favor the synthesis of polyphenols 
in grapes. However, if on the one hand nitrogen fertilization promotes high crop yield, on the other hand high nitrogen concentrations in vines have several shortcomings, including an excessive increase in vegetative growth, which can compete with sugar translocation in berries [1], delay of berry ripening [7], reduction in color intensity in the fruit [8] and increase in fungal susceptibility [9].

Nowadays, researchers use different tools to manage $\mathrm{N}$ supply, such as chemical analyses of plant tissues [10], instrumental portable detectors as SPAD colorimetric meter or multiplex [11], and a remote sensing approach [12]. In contrast, grape growers are concerned about the negative impact of excess nitrogen, so that they reduce or exclude $\mathrm{N}$ fertilization in the Mediterranean area. Notwithstanding, vineyard nitrogen management is critical to regulate vine vigor, source/sink relationships and canopy microclimate to achieve optimal berry development and quality with respect to the wine type targeted [13].

Among the grapevine pests of high economic importance worldwide [14], the vine mealybug (VMB), Planococcus ficus (Signoret) (Hemiptera: Pseudococcidae), causes severe direct damage, including sap depletion, plant weakening, and honeydew production. Additionally, high pest infestation increases the risk of ochratoxin contamination on berries [15] and reduces the quality of white and red wines [16]. The VMB is one of the most difficult key pests to control because of its cryptic behavior. In fact, mealybugs are mostly located under the bark and on roots and are protected from insecticides, especially those exhibiting contact toxicity. As a consequence, the effectiveness of conventional chemical control programs is often unsatisfactory, to the extent that a wide range of alternative strategies have been developed, such as mating disruption and biological control [17-20].

Recently, the use of several insecticides commonly used for conventional VMB control, including thiamethoxam, imidacloprid, chlorpyrifos, and chlorpyrifos-methyl, has been restricted in Europe [21-24]. Similarly, the use of chlorpyrifos, which is the most common pesticide sprayed for VMB and ant control in vineyards, ceased in California at the end of 2020, with an expected increase in pest management costs of about 4 mil USD [25].

This scenario requires further advances in non-chemical strategies and a compelling integration of all available tools to pursue an effective VMB control. In this perspective, cultural practices may play a key role, as they impact the vineyard agroecosystem as a whole and deeply affect the fitness of pests and diseases. In fact, nitrogen fertilization and soil management practices that promoted $\mathrm{N}$ accumulation in the soil, such as tillage and legume cover crop, also promoted infections by powdery and downy mildew [26] and population growth of the vine mealybug $[27,28]$. In addition, removal of supernumerary leaves and secondary shoots in summer may concur to reduce VMB density by enhancing the foraging activity of parasitoids and aerating the canopy, thereby increasing the effectiveness of chemical applications [29]. Winter debarking may further reduce the pest population by exposing overwintering mealybugs to unfavorable climatic conditions and winter spray applications [30]. Pruning and irrigation affected the density also of other key grape pests. For instance, removal of bunch-zone leaves prevented economic damage by the European grapevine moth and grey mold [31], whereas water provision promoted the development of grapevine leafhoppers [32]. The wide literature on this subject highlights that cultural practices, including fertilization, should be included as sustainable control techniques within a multi-disciplinary approach to grape pest control [33,34]. Although such practices may not be effective as stand-alone control tactics, they can be suitably included in integrated pest control programs.

The aim of the present work was to investigate under field conditions the interdisciplinary implications of nitrogen fertilization by evaluating its influence on both grape yield components and must composition, and the development and fitness of the VMB.

\section{Materials and Methods}

\subsection{Study Site and Experimental Design}

The experiment was carried out in 2014 and 2015 in a commercial vineyard of cultivar 'Carignano', located at $40 \mathrm{~m}$ a.s.l. in northwestern Sardinia (Italy, $40.664327 \mathrm{~N}, 8.276859$ E). 
'Carignano', also known as 'Cariñena', 'Mazuela', 'Carignan noir', or 'Nerello cappuccino', is mainly cultivated in Chile, Spain, France, and southwestern Sardinia, where it is spread in areas characterized by sandy soil and no irrigation [35]. In Sardinia, 16 tons ha $^{-1}$ is the maximum quantity of 'Carignano' grape allowed by the production specification.

Vines were planted in 1998 and grafted onto 779 P rootstock in alluvial calcareous soil, trained by a spur-pruned cordon (commonly with five spurs with two buds each), and spaced $2.7 \mathrm{~m}$ and $1.0 \mathrm{~m}$ between and within rows, respectively. Vineyard rows were north-south oriented. Soil was managed with herbicide under the vines and with natural grass cover between rows. From late June to mid-August, two irrigations were applied in 2014 (ca. $600 \mathrm{~m}^{3} \mathrm{ha}^{-1}$ year $^{-1}$ ) and three irrigations were done in 2015 (ca. $900 \mathrm{~m}^{3} \mathrm{ha}^{-1}$ year ${ }^{-1}$ ), using a drip system. In this area, grape growers commonly apply from 0 to $60-80$ Units ha $^{-1}$ year $^{-1}$ as standard fertilization, mainly depending on soil fertility and oenological objectives. Before the beginning of the experiment, the soil was characterized by sand $49 \%$, clay $26 \%$, and silt $25 \%$, pH 7.5 , and $1.7 \mathrm{~g} \mathrm{~kg}^{-1}$ of nitrogen, $26 \mathrm{mg} \mathrm{kg}^{-1}$ of phosphorus, $18 \mathrm{~g} \mathrm{~kg}^{-1}$ of organic matter, and $8 \mathrm{~g} \mathrm{~kg}^{-1}$ of organic C.

The trial was carried out in a randomized complete block design with three replications of nine vines each. Nitrogen treatments were applied on 23 April 2014 and 4 May 2015 as ammonium nitrate (YaraBela EXTRAN 33,5, $335 \mathrm{~g} \mathrm{~N} \mathrm{~kg}^{-1}$, Yara Italia S.P.A. Milano, Italy). The following nitrogen supplies were compared: 0, 80 Units and 160 Units of mineral $\mathrm{N}$. These nitrogen levels cover a range from no supply (0 Units) to standard fertilization (80 Units) and excessive supply (160 Units). In order to provide 80 Units and 160 Units of nitrogen per hectare, the experimental plots were fertilized with $240 \mathrm{~kg} \mathrm{ha}^{-1}$ and $480 \mathrm{~kg} \mathrm{ha}^{-1}$ of ammonium nitrate, respectively.

\subsection{Field Measurements}

\subsubsection{Weather Data}

Minimum, mean, and maximum temperature and rainfall were recorded daily from 1 March 2014 to 1 March 2015 to harvest by a weather station located in the southern edge of the vineyard (40.663111 N, $8.278000 \mathrm{E})$. Accumulated growing degree days (GDD) were calculated from 1 March to 30 October as: $\left[\left(T_{\max }+T_{\min }\right) / 2\right]-\mathrm{T}_{\text {base }}$, where $\mathrm{T}_{\max }=$ daily maximum temperature, $T_{\min }=$ daily minimum temperature, $T_{\text {base }}=$ base temperature for grapevine development $\left(10^{\circ} \mathrm{C}\right)[36]$.

With regard to the $\mathrm{VMB}$, average daily maximum temperatures higher than the upper mealybug developmental threshold $\left(35.6^{\circ} \mathrm{C}\right)$ and minimum temperatures lower than the lower developmental threshold $\left(16.6^{\circ} \mathrm{C}\right)$ were considered extreme weather conditions that could affect its development and survival [37].

2.2.2. Leaf Nutrient Composition, Vegetative Growth, Crop Yield, and Must Quality of Grapevines

The number of buds, shoots and clusters per vine was recorded to determine bud fertility. Nitrogen content on grape leaves was determined non-invasively by a SPAD 502 Chlorophyll Meter (Minolta, Osaka, Japan). In fact, nitrogen content by Kjeldahl method and chlorophyll concentrations on leaves are strictly related [11,38], and a highly linear positive correlation between these two parameters was recorded in a previous study in the same area [27]. Measurements were carried out six times during both grape growing seasons on five basal leaves on each plant artificially infested with mealybugs (see Section 2.2.3. for details) from 8 May to 1 August 2014 and from 20 May to 13 August 2015.

Grapes from all treatments were harvested on the same date in each year: 28 September 2014 and 5 October 2015. Yield and its components (cluster and berry weights and number of clusters per vine) were recorded by weighing ten clusters randomly chosen from each plot and ten berries randomly picked from each of those clusters, for a total of 100 berries per plot. At harvest, 300 berries were randomly taken from each treatment replicate in order to measure total soluble solids (TSS, ${ }^{\circ} \mathrm{Brix}$ ), titratable acidity (TA, g tartaric acid L $\left.{ }^{-1}\right), \mathrm{pH}$, total phenols $\left(\mathrm{mg} \mathrm{L}^{-1}\right)$, and total anthocyanins $\left(\mathrm{mg} \mathrm{L}^{-1}\right)$. 
Total soluble solids were determined by handheld refractometer, $\mathrm{pH}$ by $\mathrm{pH}$ meter, and TA by titration. Total phenols and anthocyanins were determined using the methodology proposed by Di Stefano and Cravero [39] after peeling the frozen berries. The leaf surface was determined at veraison using a planimeter (LI-3100C Area Meter, Li-COR Inc., Lincoln, NE, USA). Two randomly-selected shoots were excised from two vines and the number of primary leaves, lateral shoots and leaves of lateral shoots was measured and recorded. Total leaf area (TLA) was determined as the sum of primary leaf area (PLA) and lateral leaf area (LLA). On three mature leaves for each treatment, the length of vein N1, N2 and N3 (O.I.V. code number 601, 602 and 603, respectively) was measured. In winter, at the dormant season, the weight of the dry pruning wood was recorded in order to estimate the vegetative growth. The weight of pruning wood was also used to calculate the Ravaz Index (yield to pruning weight ratio).

\subsubsection{Development and Reproductive Parameters of Planococcus ficus}

The response of $P$. ficus to nitrogen fertilization was evaluated on grapevines provided with the different nitrogen rates $(0,80$ Units and 160 Units). First-instar nymphs to be used in the field experiment were obtained from a mass-rearing colony established at the Department of Agricultural Sciences of the University of Sassari (Italy) and were maintained on sprouted potatoes at $25{ }^{\circ} \mathrm{C} \pm 2{ }^{\circ} \mathrm{C}, 60-70 \% \mathrm{RH}$, in constant darkness. Ovipositing females were collected from the colony with a sable brush, gently placed on cardboard strips and allowed to oviposit. After $24 \mathrm{~h}$, females were removed and eggs of the same age were divided into batches of 500 each under a dissecting microscope. Egg batches were stored in plastic containers $(3 \times 3 \mathrm{~cm}$, diameter $\times$ height $)$ in a climatic chamber at $25^{\circ} \mathrm{C}, 60 \% \mathrm{RH}$ and $12: 12$ (L:D) photoperiod for 7 days, which is the time required for egg hatching of VMB [40].

Hatching first-instar nymphs were used to artificially infest three experimental grapevines on 3 June 2014 and 17 June 2015 by securing the plastic container to a median leaf of a shoot. Nymphs were confined in 3-4 leaves of the infested shoot by a cage of spun-bonded polypropylene fabric (Agribon AG-15, $18.65 \mathrm{~g} \mathrm{~m}^{-2}, 90 \%$ light transmission) secured with elastic bands at both ends. Cages prevented mealybugs to spread in the whole canopy and also excluded natural enemies and mealybug-tending ants. Before infestation, experimental grapevines were debarked and carefully inspected to remove pre-existing mealybugs from canopy and wood.

Starting from three weeks after infestation, plant organs inside cages were carefully inspected daily, and the first 30 females per plant at the onset of oviposition were collected with a sable brush and isolated in cylindrical containers $(3 \times 3 \mathrm{~cm}$, diameter $\times$ height $)$. Date of collection, plant, plot, and treatment were reported on the lids of the containers, which were stored in a cooler until return to the laboratory and then kept at laboratory temperature. After two months, the number of dead nymphs and unhatched eggs inside the containers was counted under a dissecting microscope in order to determine fecundity (firstinstar nymphs + unhatched eggs) and fertility (first-instar nymphs / (first-instar nymphs + unhatched eggs $) \times 100$ ) of mealybugs. For the same females, the development time from egg hatch to oviposition was also calculated (date of oviposition onset-date of egg release). The field trial ended two months after infestation, when the residual mealybugs were counted and removed from plants. Survivorship of the vine mealybug to adulthood was assessed by counting adult females, as males are very small and short-lived. The survival rate was calculated as: adult females /(released eggs $\times$ percentage of female eggs), assuming a percentage of female eggs equal to $60.3 \%$ [27].

\subsection{Data Analysis}

The VMB developmental and reproductive parameters, SPAD values, and grape vegetative growth and yield data were compared among treatments by generalized linear mixed models using GLIMMIX procedure (SAS version 9.2, SAS Institute Inc., Cary, NC, USA). The nitrogen dose and year were treated as a fixed effect and plot as a random effect. 
Numerical data were preliminary tested for homoscedasticity by the Bartlett's test and $\log (x+1)$ transformed when needed to fulfill assumptions of homoscedasticity, whereas percentage data were assumed to follow a binomial distribution. Fixed main-effects and interactions were compared by Tukey's post hoc test with significance level set at 0.05 . When the interaction $\mathrm{N}$ dose $\times$ year was significant, significant differences among nitrogen rates were further investigated within years.

\section{Results}

\subsection{Weather}

The meteorological conditions were different over the two years of the trial (Figure 1). The mean daily air temperature of the experimental site during the growing season (1 March to 30 September) was $19.1^{\circ} \mathrm{C}$ and $20.1^{\circ} \mathrm{C}$ in 2014 and 2015 , respectively. The first year (2014) was characterized by a higher rainfall from March to May, with $152 \mathrm{~mm}$, whereas the following year was drier, with only $27.5 \mathrm{~mm}$ of rainfall in the same period. From June to August, rainfall was limited in both years and amounted to $30 \mathrm{~mm}$ and $12.5 \mathrm{~mm}$ in 2014 and 2015, respectively. Accumulated growing degree days from 1 March to 30 October were higher in 2015 (2458 GDD) than in 2014 (2158 GDD). These data clearly differentiate the two vintages: 2014 was characterized by higher rainfall and lower temperatures than 2015, which in turn was drier and warmer than the preceding year.

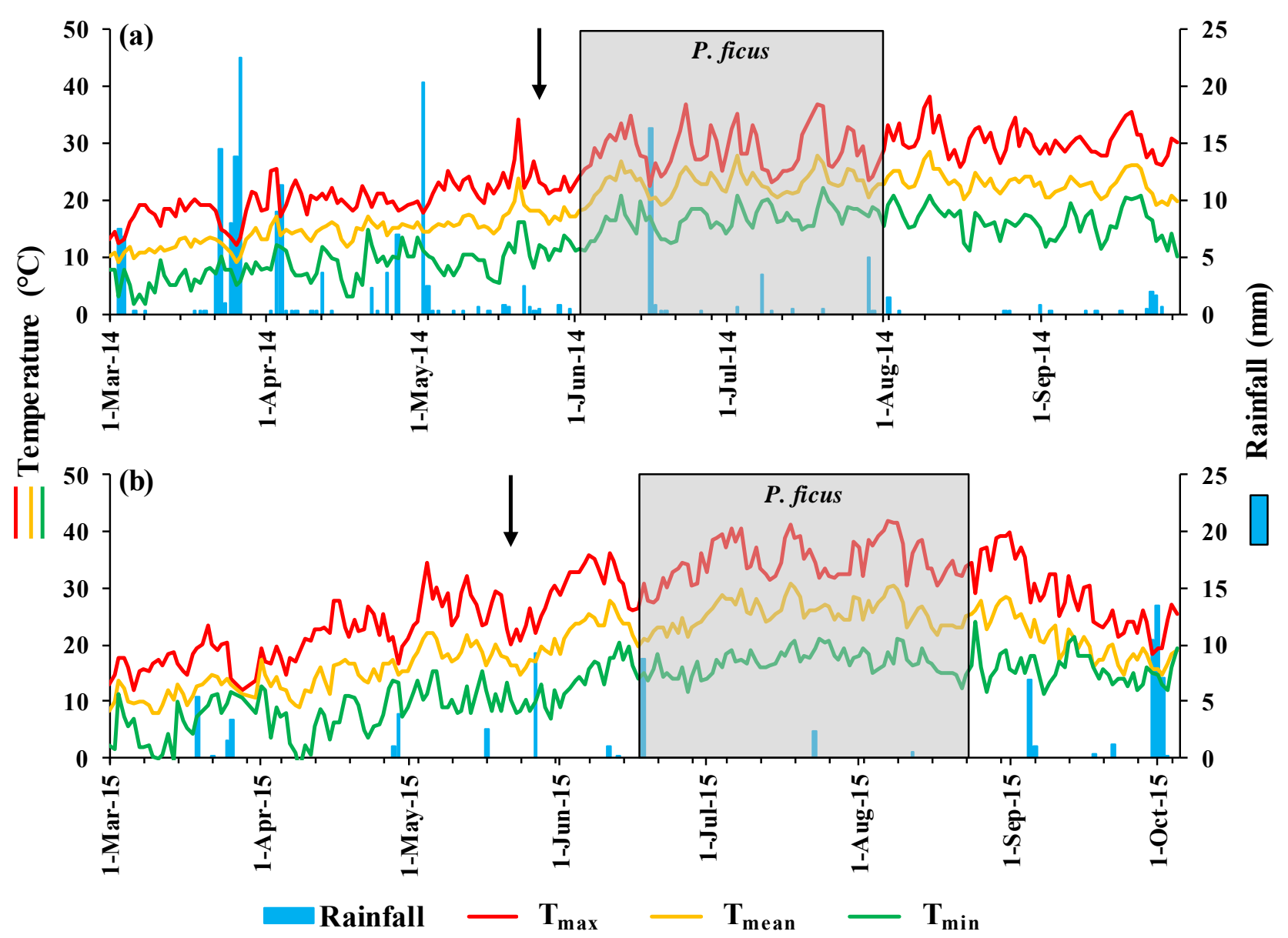

Figure 1. Average daily rainfall and maximum $\left(\mathrm{T}_{\max }\right)$, mean $\left(\mathrm{T}_{\text {mean }}\right)$, and minimum $\left(\mathrm{T}_{\min }\right)$ temperature patterns during the grape growing season in (a) 2014 and (b) 2015. Shaded areas indicate the periods of Planococcus ficus field observations and arrows indicate the dates of anthesis.

In 2014, the field observations on mealybugs lasted from 3 June to 1 August (Figure 1). In that period, the average minimum, mean, and maximum temperatures were $16.7^{\circ} \mathrm{C}$, 
$22.9^{\circ} \mathrm{C}$, and $28.8^{\circ} \mathrm{C}$, respectively. With respect to the developmental threshold of VMB estimated by Walton and Pringle [37], the average daily maximum temperature exceeded the upper threshold $\left(35.6^{\circ} \mathrm{C}\right)$ in 3 days. The total rainfall during the VMB field observations was $27.8 \mathrm{~mm}$ and the mean relative humidity $(\mathrm{RH})$ was $67.0 \%$.

In 2015, mealybugs were observed in the field from 17 June to 22 August (Figure 1), during which the daily mean temperature averaged $25.5^{\circ} \mathrm{C}$ and average daily minimum and maximum temperatures were $16.8{ }^{\circ} \mathrm{C}$ and $34.8^{\circ} \mathrm{C}$, respectively. Interestingly, the average daily maximum temperature was higher than the upper threshold in 27 days. The most relevant rain events occurred on 18 June $(8.8 \mathrm{~mm})$ and 23 July $(2.3 \mathrm{~mm})$, for a total rainfall of $11.6 \mathrm{~mm}$, whereas mean $\mathrm{RH}$ was $69 \%$.

During the mealybug trials, the weather was hotter in 2015 than 2014, especially the average daily maximum temperature, which was $6{ }^{\circ} \mathrm{C}$ higher in 2015. Overall, VMB was exposed to more critical weather conditions in 2015 , as the upper developmental threshold was exceeded in 27 days compared to 3 days in 2014 and total rainfall was $16.2 \mathrm{~mm}$ lower.

\subsection{Plant Nitrogen Status, Vegetative Growth, Crop Yield, and Must Quality of Grapevines}

In both years, the SPAD pattern increased in all treatments until late June-early July, when values became steady or decreased, as in unfertilized grapes in 2014 (Table 1). SPAD values were significantly higher in 2015 than in 2014. In fact, grapes provided with 160 Units of nitrogen showed SPAD values higher than 50 from June to August 2015, whereas the highest value was 46.6 in mid-June in 2014. The leaf nitrogen content, assessed by SPAD meter, was affected by the nitrogen rates provided to grapes in 2014 and 2015, with significantly higher values in plants fertilized with 80 Units and 160 Units than in unfertilized plants in both years (Table 1).

Table 1. Patterns of SPAD values (mean \pm SE) on leaves of field-grown grapevines supplied with different nitrogen rates in 2014 and 2015.; The value within curly brackets denotes the number of replicates; values within round brackets indicate the days before or after anthesis.

\begin{tabular}{|c|c|c|c|c|c|c|c|}
\hline $\begin{array}{l}\text { N Dose (Units) } \\
\left(\mathrm{kg} \mathrm{ha}^{-1}\right)\end{array}$ & SPAD Value & E) $\{9\}$ & & & & & \\
\hline 2014 & 8 May $(-17)$ & 20 May $(-5)$ & 3 June (9) & 24 June (30) & 16 July (52) & 1 August (68) & \\
\hline 0 & $34.49 \pm 0.53 \mathrm{~b}$ & $36.49 \pm 0.74 c$ & $37.58 \pm 0.43 b$ & $38.49 \pm 0.69 c$ & $32.79 \pm 0.68 c$ & $33.79 \pm 0.97 b$ & \\
\hline 80 & $36.69 \pm 0.66 a$ & $39.99 \pm 0.54 b$ & $42.90 \pm 0.94 \mathrm{a}$ & $44.50 \pm 0.87 b$ & $42.18 \pm 0.95 b$ & $42.96 \pm 0.67 \mathrm{a}$ & \\
\hline 160 & $38.17 \pm 0.51 \mathrm{a}$ & $41.61 \pm 0.54 \mathrm{a}$ & $44.47 \pm 0.63 \mathrm{a}$ & $46.60 \pm 0.88 \mathrm{a}$ & $45.20 \pm 0.76 \mathrm{a}$ & $44.73 \pm 0.75 a$ & \\
\hline 2015 & & 20 May $(-2)$ & 5 June (14) & 19 June (28) & 24 July (63) & 7 August (77) & $\begin{array}{l}2 \text { September } \\
(103)\end{array}$ \\
\hline 0 & & $39.44 \pm 0.77 c$ & $44.97 \pm 0.65 b$ & $46.24 \pm 0.54 c$ & $44.07 \pm 0.93 b$ & $44.70 \pm 1.06 b$ & $43.80 \pm 0.92 b$ \\
\hline 80 & & $43.53 \pm 0.37 b$ & $49.06 \pm 0.39 \mathrm{a}$ & $50.31 \pm 0.43 b$ & $49.71 \pm 0.59 \mathrm{a}$ & $49.72 \pm 0.74 \mathrm{a}$ & $49.14 \pm 0.71 \mathrm{a}$ \\
\hline 160 & & $46.23 \pm 0.44 \mathrm{a}$ & $50.71 \pm 0.88 \mathrm{a}$ & $51.51 \pm 0.37 \mathrm{a}$ & $51.59 \pm 0.38 \mathrm{a}$ & $51.19 \pm 0.64 \mathrm{a}$ & $49.10 \pm 0.69 \mathrm{a}$ \\
\hline \multicolumn{8}{|l|}{ Statistics $^{1}$} \\
\hline $\mathrm{N}$ dose & ** & $* *$ & ** & $* *$ & $* *$ & ** & $* *$ \\
\hline Year & & $* *$ & $* *$ & $* *$ & $* *$ & $* *$ & \\
\hline $\mathrm{N}$ dose $\times$ year & & n.s. & n.s. & n.s. & $* *$ & * & \\
\hline
\end{tabular}

${ }^{1}$ Means in columns within each year followed by different letters are significantly different $(p<0.05)$ by Tukey's test. ${ }^{* *}=p<0.01$; $*=p<0.05 ;$ n.s. $=$ not significant.

The primary and lateral leaf areas per vine, and consequently the total leaf area, were higher in vines provided with nitrogen fertilization (Table 2). In particular, plants fertilized in 2014 with 80 Units and 160 Units showed the primary and lateral leaf areas significantly greater than unfertilized vines of about $24 \%$ and $40 \%$, respectively. In the following year, the differences between fertilized and unfertilized vines persisted, although the greater total leaf area of vines fertilized with 80 Units and 160 Units was mainly due to a greater lateral leaf area. The pruning weight increased significantly in $\mathrm{N}$-fertilized vines compared with unfertilized vines in both vintages.

The yield per vine was higher in plants subjected to nitrogen fertilization (Table 2), with both 80 Unit and 160 Unit treatments showing a higher yield than the unfertilized 
vines. The berry weight did not differ significantly among treatments, although it tended to be higher in vines provided with $\mathrm{N}$ fertilization. On the contrary, the cluster weight was higher in the 160 Unit treatment in 2014 and in both fertilized treatments in 2015 than in the control vines (Table 2). The Ravax index ranged from 2.82 to 3.86 in 2014 and from 4.46 to 5.90 in 2015.

Table 2. Effect of different nitrogen rates on leaf area and yield parameters of cv. 'Carignano' grapevine (mean \pm SE). Values within curly brackets denote the number of replicates.

\begin{tabular}{|c|c|c|c|c|c|c|c|c|}
\hline $\begin{array}{l}\text { N Dose (Units) } \\
\left(\mathrm{kg} \mathrm{ha}^{-1}\right)\end{array}$ & $\begin{array}{l}\text { Primary Leaf } \\
\text { Area (PLA) } \\
\left(\mathrm{m}^{2}\right)\{12\}\end{array}$ & $\begin{array}{l}\text { Lateral Leaf } \\
\text { Area (LLA) } \\
\left(\mathrm{m}^{2}\right)\{12\}\end{array}$ & $\begin{array}{l}\text { Total Leaf } \\
\text { Area (TLA) } \\
\left(\mathrm{m}^{2}\right)\{12\}\end{array}$ & $\begin{array}{l}\text { Pruning } \\
\text { Weight (kg) } \\
\{12\}\end{array}$ & $\begin{array}{l}\text { Berry Weight } \\
\text { (g) }\{18\}\end{array}$ & $\begin{array}{l}\text { Cluster Weight } \\
\text { (g) }\{18\}\end{array}$ & $\begin{array}{l}\text { Cluster Vine }{ }^{-1} \\
\text { (no.) }\{18\}\end{array}$ & $\begin{array}{l}\text { Yield Vine }^{-1} \\
\text { (kg) }\{18\}\end{array}$ \\
\hline \multicolumn{9}{|l|}{2014} \\
\hline 0 & $2.06 \pm 0.12 b$ & $1.50 \pm 0.09 \mathrm{~b}$ & $3.55 \pm 0.17 b$ & $0.56 \pm 0.06 \mathrm{~b}$ & $2.63 \pm 0.11 \mathrm{a}$ & $245.15 \pm 14.37 b$ & $8.44 \pm 0.65 \mathrm{a}$ & $2.16 \pm 0.15 b$ \\
\hline 80 & $2.71 \pm 0.16 \mathrm{a}$ & $2.57 \pm 0.13 \mathrm{a}$ & $5.28 \pm 0.16 \mathrm{a}$ & $0.95 \pm 0.07 \mathrm{a}$ & $2.59 \pm 0.10 \mathrm{a}$ & $280.91 \pm 18.07 b$ & $9.33 \pm 0.78 \mathrm{a}$ & $2.68 \pm 0.26 \mathrm{a}$ \\
\hline 160 & $2.71 \pm 0.12 \mathrm{a}$ & $2.49 \pm 0.15 \mathrm{a}$ & $5.20 \pm 0.19 a$ & $0.88 \pm 0.06 \mathrm{a}$ & $2.64 \pm 0.13 \mathrm{a}$ & $389.19 \pm 24.14 \mathrm{a}$ & $7.78 \pm 0.36 \mathrm{a}$ & $3.09 \pm 0.24 \mathrm{a}$ \\
\hline \multicolumn{9}{|l|}{2015} \\
\hline 0 & $3.10 \pm 0.07 b$ & $1.27 \pm 0.05 b$ & $4.36 \pm 0.09 \mathrm{~b}$ & $0.63 \pm 0.02 b$ & $2.75 \pm 0.10 \mathrm{a}$ & $269.11 \pm 17.55 b$ & $12.78 \pm 0.89 \mathrm{a}$ & $3.72 \pm 0.18 b$ \\
\hline 80 & $3.65 \pm 0.18 \mathrm{a}$ & $3.00 \pm 0.13 \mathrm{a}$ & $6.65 \pm 0.28 \mathrm{a}$ & $0.86 \pm 0.05 \mathrm{a}$ & $2.93 \pm 0.09 \mathrm{a}$ & $366.03 \pm 13.82 \mathrm{a}$ & $11.56 \pm 0.78 \mathrm{a}$ & $4.59 \pm 0.17 \mathrm{a}$ \\
\hline 160 & $3.34 \pm 0.25 \mathrm{a}$ & $2.86 \pm 0.23 \mathrm{a}$ & $6.21 \pm 0.44 \mathrm{a}$ & $1.02 \pm 0.09 \mathrm{a}$ & $3.04 \pm 0.10 \mathrm{a}$ & $374.83 \pm 14.57 \mathrm{a}$ & $11.11 \pm 0.61 \mathrm{a}$ & $4.55 \pm 0.21 \mathrm{a}$ \\
\hline \multicolumn{9}{|l|}{ Statistics ${ }^{1}$} \\
\hline $\mathrm{N}$ dose & $* *$ & $* *$ & $* *$ & $* *$ & n.s. & $* *$ & n.s. & $* *$ \\
\hline Year & $* *$ & n.s. & $* *$ & n.s. & $* *$ & $*$ & $* *$ & $* *$ \\
\hline $\mathrm{N}$ dose $\times$ year & n.s. & $*$ & n.s. & n.s. & n.s. & * & n.s. & n.s. \\
\hline
\end{tabular}

${ }^{1}$ Means in columns within each year followed by different letters are significantly different $(p<0.05)$ by Tukey's test. ${ }^{* *}=p<0.01$;

$*=p<0.05 ;$ n.s. $=$ not significant.

The number of leaves of the primary shoot was not statistically different among treatments (Table 3). In relation to leaf morphology characteristics on primary shoots, nitrogen fertilization favored a greater length of the N1 vein in vines fertilized with 160 Units. The length of N2 and N3 veins on main leaves was not influenced by fertilization. On the contrary, the lateral shoot of vines fertilized with 80 Unit and 160 Units exhibited a significantly higher number of leaves than unfertilized vines. Regarding the leaf morphology characteristics on lateral shoot, the length of N1, N2 and N3 veins was generally higher as the imposed fertilization levels increased.

Table 3. Effect of different nitrogen rates on leaf morphological characteristics (mean $\pm \mathrm{SE}$ ). Values within curly brackets denote the number of replicates.

\begin{tabular}{|c|c|c|c|c|c|c|c|c|}
\hline $\begin{array}{l}\text { N Dose (Units) } \\
\left(\mathrm{kg} \mathrm{ha}^{-1}\right)\end{array}$ & $\begin{array}{l}\text { Primary Shoot }\{9\} \\
\text { Leaves } \\
\text { (no.) }\end{array}$ & $\begin{array}{l}\text { Length N1 } \\
\text { (cm) }\end{array}$ & $\begin{array}{l}\text { Length N2 } \\
\text { (cm) }\end{array}$ & $\begin{array}{l}\text { Length N3 } \\
\text { (cm) }\end{array}$ & $\begin{array}{l}\text { Lateral Shoot }\{9\} \\
\text { Leaves } \\
\text { (no.) }\end{array}$ & $\begin{array}{l}\text { Length N1 } \\
\text { (cm) }\end{array}$ & $\begin{array}{l}\text { Length N2 } \\
\text { (cm) }\end{array}$ & $\begin{array}{l}\text { Length N3 } \\
\text { (cm) }\end{array}$ \\
\hline \multicolumn{9}{|l|}{2014} \\
\hline 0 & $10.9 \pm 0.5 \mathrm{a}$ & $15.5 \pm 0.9 \mathrm{~b}$ & $12.3 \pm 0.7 \mathrm{a}$ & $12.9 \pm 0.7 \mathrm{a}$ & $21.6 \pm 3.1 \mathrm{~b}$ & $7.0 \pm 0.6 \mathrm{~b}$ & $6.1 \pm 0.4 \mathrm{a}$ & $6.6 \pm 0.6 \mathrm{~b}$ \\
\hline 80 & $11.4 \pm 0.4 \mathrm{a}$ & $15.5 \pm 0.3 \mathrm{ab}$ & $12.8 \pm 0.4 \mathrm{a}$ & $12.8 \pm 0.3 \mathrm{a}$ & $29.6 \pm 2.0 \mathrm{a}$ & $9.9 \pm 0.5 \mathrm{a}$ & $8.5 \pm 0.2 b$ & $8.4 \pm 0.3 \mathrm{a}$ \\
\hline 160 & $13.2 \pm 0.7 \mathrm{a}$ & $16.3 \pm 0.2 \mathrm{a}$ & $12.8 \pm 0.2 \mathrm{a}$ & $13.1 \pm 0.4 \mathrm{a}$ & $33.2 \pm 1.7 \mathrm{a}$ & $8.2 \pm 0.2 \mathrm{a}$ & $6.7 \pm 0.4 \mathrm{a}$ & $7.1 \pm 0.2 \mathrm{a}$ \\
\hline \multicolumn{9}{|l|}{2015} \\
\hline 0 & $17.3 \pm 1.0 \mathrm{a}$ & $14.0 \pm 0.4 \mathrm{~b}$ & $12.2 \pm 0.7 \mathrm{a}$ & $13.3 \pm 0.4 \mathrm{a}$ & $19.3 \pm 2.3 b$ & $7.2 \pm 0.7 \mathrm{~b}$ & $6.1 \pm 0.4 \mathrm{c}$ & $6.2 \pm 0.4 b$ \\
\hline 80 & $16.3 \pm 1.4 \mathrm{a}$ & $15.1 \pm 0.8 \mathrm{ab}$ & $13.7 \pm 1.1 \mathrm{a}$ & $12.4 \pm 1.2 \mathrm{a}$ & $35.7 \pm 2.2 \mathrm{a}$ & $7.7 \pm 0.2 \mathrm{a}$ & $7.3 \pm 0.3 b$ & $7.0 \pm 0.2 \mathrm{a}$ \\
\hline 160 & $14.0 \pm 1.3 \mathrm{a}$ & $16.0 \pm 0.2 \mathrm{a}$ & $14.1 \pm 0.4 \mathrm{a}$ & $12.8 \pm 0.6 \mathrm{a}$ & $32.7 \pm 4.0 \mathrm{a}$ & $8.6 \pm 0.6 \mathrm{a}$ & $8.3 \pm 0.4 \mathrm{a}$ & $7.6 \pm 0.5 \mathrm{a}$ \\
\hline \multicolumn{9}{|l|}{ Statistics $^{1}$} \\
\hline $\mathrm{N}$ dose & n.s. & $*$ & n.s. & n.s. & $* *$ & $* *$ & $* *$ & $*$ \\
\hline Year & $* *$ & n.s. & n.s. & n.s. & n.s. & * & n.s. & * \\
\hline $\mathrm{N}$ dose $\times$ year & $* *$ & n.s. & n.s. & n.s. & n.s. & n.s. & * & n.s. \\
\hline
\end{tabular}

${ }^{1}$ Means in columns within each year followed by different letters are significantly different $(p<0.05)$ by Tukey's test. ${ }^{* *}=p<0.01$;

$*=p<0.05 ;$ n.s. $=$ not significant.

Focusing on must quality (Table 4), TSS differed significantly between vintages, but not among treatments. However, a clear trend suggests a higher sugar level in unfertilized vines. The tritatable acidity and $\mathrm{pH}$ values as well as total anthocyanins were not influenced by nitrogen fertilization, whereas the different levels of nitrogen influenced the total polyphenol concentration in both years, with a reduction in total polyphenols in the berry at increasing nitrogen doses. 
Table 4. Effect of different nitrogen rates on must composition (mean $\pm \mathrm{SE}$ ). Values within curly brackets denote the number of replicates.

\begin{tabular}{|c|c|c|c|c|c|}
\hline $\begin{array}{l}\text { N Dose (Units) } \\
\left(\mathrm{kg} \mathrm{ha}^{-1}\right)\end{array}$ & $\begin{array}{l}\text { Total Soluble } \\
\text { Solids ( }{ }^{\circ} \text { Brix) }\{9\}\end{array}$ & $\mathrm{pH}\{9\}$ & $\begin{array}{l}\text { Tritatable Acidity } \\
\left(\mathrm{g} \mathrm{L}^{-1}\right)\{9\}\end{array}$ & $\begin{array}{l}\text { Total Anthocyanins } \\
\left(\mathrm{mg} \mathrm{L}^{-1}\right)\{9\}\end{array}$ & $\begin{array}{l}\text { Total Polyphenols } \\
\left(\mathrm{mg} \mathrm{L}^{-1}\right)\{9\}\end{array}$ \\
\hline \multicolumn{6}{|l|}{2014} \\
\hline 0 & $22.1 \pm 1.2 \mathrm{a}$ & $3.63 \pm 0.03 \mathrm{a}$ & $5.28 \pm 0.20 \mathrm{a}$ & $436.4 \pm 54.1 \mathrm{a}$ & $1651.5 \pm 86.1 \mathrm{a}$ \\
\hline 80 & $20.8 \pm 0.8 \mathrm{a}$ & $3.53 \pm 0.01 \mathrm{a}$ & $5.60 \pm 0.26 \mathrm{a}$ & $406.0 \pm 63.2 \mathrm{a}$ & $1400.6 \pm 136.2 b$ \\
\hline 160 & $20.9 \pm 0.9 \mathrm{a}$ & $3.47 \pm 0.10 \mathrm{a}$ & $5.40 \pm 0.17 \mathrm{a}$ & $470.9 \pm 37.5 \mathrm{a}$ & $1317.3 \pm 25.3 \mathrm{~b}$ \\
\hline \multicolumn{6}{|l|}{2015} \\
\hline 0 & $20.1 \pm 0.2 \mathrm{a}$ & $3.68 \pm 0.06 \mathrm{a}$ & $4.80 \pm 0.09 \mathrm{a}$ & $596.6 \pm 28.7 a$ & $1248.9 \pm 144.2 \mathrm{a}$ \\
\hline 80 & $19.4 \pm 0.4 \mathrm{a}$ & $3.70 \pm 0.05 \mathrm{a}$ & $5.00 \pm 0.26 \mathrm{a}$ & $522.3 \pm 34.8 \mathrm{a}$ & $1127.7 \pm 213.0 \mathrm{ab}$ \\
\hline 160 & $19.0 \pm 0.2 \mathrm{a}$ & $3.68 \pm 0.02 \mathrm{a}$ & $5.10 \pm 0.09 \mathrm{a}$ & $618.3 \pm 80.2 \mathrm{a}$ & $1016.4 \pm 197.6 \mathrm{~b}$ \\
\hline \multicolumn{6}{|l|}{ Statistics $^{1}$} \\
\hline $\mathrm{N}$ dose & n.s. & n.s. & n.s. & n.s. & * \\
\hline Year & * & * & $* *$ & * & $* *$ \\
\hline $\mathrm{N}$ dose $\times$ year & n.s. & n.s. & n.s. & n.s. & * \\
\hline
\end{tabular}

${ }^{1}$ Means in columns within each year followed by different letters are significantly different $(p<0.05)$ by Tukey's test. ${ }^{* *}=p<0.01$; $*=p<0.05 ;$ n.s. $=$ not significant.

\subsection{Development and Reproductive Parameters of Planococcus ficus}

In both experimental years, the development time of $P$. ficus from hatching egg to ovipositing female was significantly longer on unfertilized grapes than on plants supplied with 80 Units and $160 \mathrm{~N}$ Units, which did not differ significantly between them (Table 5). Development time in fertilized plants ranged from 32.3 to 32.8, whereas mealybugs reared in untreated grapevines started ovipositing after 35.3 and 37.3 days in 2014 and 2015, respectively.

Table 5. Effect of different nitrogen rates on developmental and reproductive parameters of Planococcus ficus (mean \pm SE). Values within curly brackets denote the number of replicates.

\begin{tabular}{|c|c|c|c|c|}
\hline N Dose (Units) (kg ha ${ }^{-1}$ ) & $\begin{array}{l}\text { Development Time } \\
\text { (Days) }\{90\}^{12}\end{array}$ & $\begin{array}{l}\text { Fecundity } \\
\text { (no. eggs) }\{90\}^{1}\end{array}$ & Fertility (\%) $\{90\}^{2}$ & Survival (\%) $\{9\}^{3}$ \\
\hline \multicolumn{5}{|l|}{2014} \\
\hline 0 & $35.31 \pm 0.20 \mathrm{~b}$ & $143.8 \pm 7.0 \mathrm{~b}$ & $95.67 \pm 0.62 \mathrm{a}$ & $29.8 \pm 3.9 b$ \\
\hline 80 & $32.82 \pm 0.11 \mathrm{a}$ & $174.4 \pm 7.5 \mathrm{a}$ & $95.59 \pm 0.91 \mathrm{a}$ & $38.8 \pm 3.6 \mathrm{a}$ \\
\hline 160 & $32.44 \pm 0.12 \mathrm{a}$ & $186.8 \pm 9.4 \mathrm{a}$ & $95.96 \pm 0.60 \mathrm{a}$ & $41.3 \pm 4.5 \mathrm{a}$ \\
\hline \multicolumn{5}{|l|}{2015} \\
\hline 0 & $37.27 \pm 0.32 b$ & $110.9 \pm 4.4 \mathrm{~b}$ & $95.05 \pm 1.04 \mathrm{a}$ & $9.5 \pm 1.1 \mathrm{~b}$ \\
\hline 80 & $32.43 \pm 0.15 \mathrm{a}$ & $143.0 \pm 5.6 \mathrm{a}$ & $95.37 \pm 0.66 \mathrm{a}$ & $15.8 \pm 2.0 \mathrm{a}$ \\
\hline 160 & $32.28 \pm 0.18 \mathrm{a}$ & $132.1 \pm 6.3 \mathrm{a}$ & $95.16 \pm 0.68 \mathrm{a}$ & $16.7 \pm 3.2 \mathrm{a}$ \\
\hline \multicolumn{5}{|l|}{ Statistics 4} \\
\hline $\mathrm{N}$ dose & $* *$ & $* *$ & n.s & $* *$ \\
\hline Year & $* *$ & $* *$ & $*$ & $* *$ \\
\hline $\mathrm{N}$ dose $\times$ year & $* *$ & n.s. & n.s. & n.s. \\
\hline
\end{tabular}

Means in columns within each year followed by different letters are significantly different (Tukey's test, $p<0.05) .{ }^{1}$ Data referred to the first 30 females/plant (90 females/treatment). ${ }^{2}$ Development time from egg hatching to oviposition onset. ${ }^{3}$ Survival of $P$. ficus females. $4 * *=p<0.01 ;{ }^{*}=p<0.05 ;$ n.s. $=$ not significant.

The fecundity of $P$. ficus females in 2014 and 2015 did not differ between females developing in $\mathrm{N}$ fertilized plants, being significantly higher in both cases than that of females in untreated plants (Table 5). Overall, fecundity was higher in 2014 than in 2015. Fertility differed significantly between years, being higher in 2014 than in 2015, whereas the $\mathrm{N}$ dose did not affect it. The survival of mealybug was significantly lower in unfertilized vines than in plants supplied with 80 Units and $160 \mathrm{~N}$ Units, which showed similar survival rates. Comparison between years highlighted a higher mealybug mortality in 2015 than in 2014. 


\section{Discussion}

The present open-field trial investigated the influence of nitrogen fertilization on yield components and must composition in 'Carignano' cultivar grapes and on the development and fitness of the VMB. The $\mathrm{N}$ status of the vines was influenced by the amount of nitrogen fertilization supplied, as shown by SPAD measurements, which were shown to be sensitive, reliable, and non-destructive indicators of the leaf $\mathrm{N}$ content, as previously observed in other studies [41,42]. It is important to highlight that SPAD measurements allowed discrimination between fertilized and non-fertilized vines but did not always differentiate between the two nitrogen levels supplied in our experiment.

The leaf area was measured at veraison, i.e., onset of ripening, when the shoot apex typically ceases to grow. Consequently, the shoot length was the same in all vines considering that shoot topping was applied at pea-size stage in all treatments. Although differences were not statistically significant, the higher $\mathrm{N}$ dose supplied promoted a reduction in the number of leaves in the primary shoot, most likely because the higher nitrogen dose favored considerably longer internodes. The consequences of $\mathrm{N}$ supply on grape yield were mainly due to differences in cluster weight and, considering that in both years the average berry weight did not vary between treatments, the higher cluster weight was most likely due to a higher number of berries per cluster in the fertilized vines. These results are in line with findings by Keller et al. [7], who showed that low nitrogen availability at bloom reduced the fruit set in the cultivar 'Cabernet Sauvignon' due to necrotic inflorescences and a lower number of clusters per vine and berries per cluster, thereby causing a decrease in yield. According to Kliewer and Dokoozlian [43], the current guidelines of optimal leaf area/crop weight ratio for a full canopy in a productive vineyard is about $0.8-1.2 \mathrm{~m}^{2} \mathrm{~kg}^{-1}$, whereas the crop yield/pruning weight ratio should range from 4 to 10 . Nitrogen supply increased the total leaf area/yield ratio, even though the lowest $\mathrm{N}$ amount supplied promoted a better increase of that ratio.

As expected, the $\mathrm{N}$ deficiency resulted in plant growth reduction and leaf chlorosis. Consequently, vines with $\mathrm{N}$ deficiency exhibited a lower leaf extension rate and smaller leaf areas than those provided with $\mathrm{N}$ sources. Overall, the applied fertilization levels affected the leaf size in primary and secondary shoots, which showed higher lengths of the observed veins.

At harvest, the $\mathrm{N}$ fertilization rates did not significantly affect tritatable acidity or total soluble solids. Nevertheless, vines supplied with the highest $\mathrm{N}$ dose had berries with lower but non-significantly different values of soluble solid contents than the unfertilized ones. In addition, $\mathrm{N}$ fertilization promoted a decrease in the sugar/acidity ratio (data not shown), suggesting a delayed fruit maturation as reported also by Keller et al. and Spayd et al. [7,8], although a reduction in soluble solid contents in must due to nitrogen fertilization was found by Delgado et al. [1]. In addition, although the aromatic component was not considered in our study, the level of grape maturity achieved significantly affected the free aroma profile, as demonstrated by Petretto et al. [44] in the cultivar 'Cannonau' in grapes and wines.

Our results showed that $\mathrm{N}$ fertilization did not affect the total anthocyanin content, but reduced polyphenol content. The observed lack of effect of $\mathrm{N}$ doses on berry weight at harvest indicates that fertilization did not lead to a dilution effect of metabolites caused by an increase in pulp/skin ratio. Because of this, the reduction in total polyphenols was likely due to variations in plant secondary metabolism mainly affecting the non-flavonoid compounds in grape. To the best of our knowledge, a few studies investigated the effect of $\mathrm{N}$ fertilization on the non-flavonoid compounds in grapes. In a survey carried out in 'Tempranillo' grapes, Portu et al. [45] showed that foliar applications of phenylalanine led to a decrease in hydroxycinnamic acid content, a non-flavonoid grape component. However, this phenomenon was not confirmed in all the experimental years and the reduction in non-flavonoid compounds in grapes was not observed when nitrogen was delivered in other chemical forms. On the other hand, other studies reported that moderate 
$\mathrm{N}$ application before bloom enhanced the anthocyanin accumulation in the grape [1] and high $\mathrm{N}$ applications promoted poor color development in the fruit [46,47].

The nitrogen fertilization significantly affected the fitness of $P$. ficus in both years, with a shorter development time on grapevines provided with nitrogen. Despite the different climatic conditions registered in 2014 and 2015, the development time from egg hatching to oviposition in fertilized grapevines was similar (32-33 days), whereas the development in unfertilized plants was slightly longer in 2015 than in 2014. This seems to indicate that mealybug development would be more sensitive to extreme thermal conditions when the pest feeds on substrates with low N content. Such results are in accordance with field studies conducted in the same area with unfertilized grapevines managed with different cover crops, as they showed P. ficus development times ranging from 32.9 to 39.8 days $[28,40]$, with lower values on plants with higher $\mathrm{N}$ content (i.e., under legume mixture cover crop) [28]. Our findings are in line with laboratory and semi-field trials on potted grapevines, in which the VMB development decreased proportionally with increasing $\mathrm{N}$ fertilization levels provided to plants [27]. Nitrogen supply to host plants provided different effects on other pseudococcid species. For instance, the citrus mealybug, Planococcus citri (Risso), showed a shorter development time on coleus plants receiving higher N concentrations [48], whereas the Madeira mealybug, Phenacoccus madeirensis Green, reared on basil showed no difference in development durations across different $\mathrm{N}$ levels [49].

The observed higher mealybug fecundity in vines supplied with $\mathrm{N}$ fertilization is in accordance with previous studies carried out on the same or congeneric species $[27,28,48,49]$. In our field study, the VMB reproductive performance did not differ between $\mathrm{N}$ treatments in the range 80-160 N Units, whereas in semi-natural conditions VMB exhibited a linear increase in fecundity when reared on pot-grown grapes provided with $0-2 \mathrm{~g} \mathrm{~L}^{-1}$ of ammonium nitrate [27]. The concentration-response of sap-sucking pests to increasing concentration of $\mathrm{N}$ differs depending on pest species and concentration range. In this regard, the population growth parameters, i.e., intrinsic and finite rates of increase and net reproductive rate, of the sugarcane mealybug, Saccharicoccus sacchari (Cockerell), increased as $\mathrm{N}$ doses increased up to a maximum value and then decreased [50], whereas the reproductive performance of some aphid species was not affected by $\mathrm{N}$ supply [51,52]. Although several other studies investigated the egg production of $P$. ficus $[18,27,53-56]$, the different experimental designs and rearing conditions applied make it difficult to compare the results. Nonetheless, when compared with other field trials in which vine mealybugs developed on cv. 'Carignano' grapevines [28,40], the highest mean fecundity was recorded in the present study (186.8 eggs female ${ }^{-1}$ ), probably as a result of the high $\mathrm{N}$ supply.

Our study highlighted that fertility did not differ significantly among treatments in both 2014 and 2015, in accordance with previous laboratory and semi-field trials on potted vines [27]. On the other hand, VMB reared on plants managed with legume covering exhibited higher fertility although differences among treatments were lower than $2 \%$ [28]. The observed significant increase in mealybug survival, due to nitrogen fertilization in both years, is supported by previous observations on pot-grown vines and vineyards with legume mixture cover crop $[27,28]$. Overall, the lower survival and fecundity of mealybugs developed on unfertilized grapevines may be due to nutritional limitations and/or lower nutritional value of phloem sap $[57,58]$. Soil management with cover crop species that participate in the $\mathrm{N}$ fixation process in the soil, e.g., legumes, can replace $\mathrm{N}$ fertilization and promote development and survival of the VMB [34]. Moreover, floor vegetation promotes the establishment of ants, which protect mealybugs from natural enemies, thereby favoring the pest infestation [59].

The present research confirms the findings of a previous study of $\mathrm{N}$ fertilization of 'Vermentino' grapevines conducted under controlled conditions, i.e., potted grapevines in a screen house [27], and supports the hypothesis that the increasing mealybug infestations recorded in different grape areas may be due to cultural systems that promoted plant vigor [60]. The different responses by P. ficus between years can be attributed to abiotic 
factors, such as temperature, which was remarkably higher in 2015, as well as water availability and canopy microclimatic conditions. In fact, water supply combined with nitrogen fertilization may affect the performance of mealybugs, as observed on the striped mealybug, Ferrisia virgata Cockerell [61].

\section{Conclusions}

The comparison of the $\mathrm{N}$ levels applied in the experiment, from no supply to a maximum supply of 160 Units $\mathrm{N} \mathrm{ha}^{-1}$, highlighted that $\mathrm{N}$ had a direct effect on grape yield, as well as on VMB population build-up. On 'Carignano' grapevines, $\mathrm{N}$ promoted a greater development of lateral shoots, without affecting the berry chemical composition. Nitrogen supply reduced the polyphenol content of grape must; however, further studies are needed to clarify which phenolic compounds and aroma components are more sensitive to $\mathrm{N}$ supply. Nitrogen supply also enhanced the fitness of the VMB, which showed shorter development time as well as increased survival and fecundity.

In a context of a more sustainable viticulture, with a reduction in chemical inputs, a proper management of fertilizer applications must take into account the effects of this practice on the entire vineyard agro-ecosystem. Our findings underline the importance of integrating cultivation and pest control techniques in order to reach the oenological goals and avoid favorable conditions for pest development. In this context, $\mathrm{N}$ fertilization should be applied carefully when high-VMB infestation levels occur. Overall, grapevine yield and mealybug development were similar in the range 80-160 N Units ha ${ }^{-1}$. Further research is needed to investigate minimum thresholds of $\mathrm{N}$ supply that ensure high-quality grape production without triggering increases in pest population.

Author Contributions: Conceptualization, A.C., L.M., G.N. and A.L.; Methodology, A.C., L.M., E.M., G.N. and A.L.; Investigation, L.M., E.M. and A.M.; Data Curation, A.C., L.M., E.M. and A.M.; Formal Analysis, A.C. and L.M.; Funding acquisition, G.N., A.L.; Writing-original draft preparation, A.C. and L.M.; Writing-review and editing, A.C., L.M., G.N. and A.L. All authors have read and agreed to the published version of the manuscript.

Funding: This study was carried out within the project "Gestione del suolo in viticoltura: effetti sulla fisiologia della pianta e sulle principali avversità biotiche" (Grant no. CRP-24791) funded by Autonomous Region of Sardinia, Italy (L.R.7/2007-Promotion of scientific research and technological innovation in Sardinia).

Institutional Review Board Statement: Not applicable.

Informed Consent Statement: Not applicable.

Data Availability Statement: The data presented in this study are available upon request from the corresponding author.

Acknowledgments: The authors thank Ana Helena Dias Francesconi from the University of Sassari for revising the manuscript.

Conflicts of Interest: The authors declare no conflict of interest.

\section{References}

1. Delgado, R.; Martin, P.; Del Alamo, M.; Gonzales, M.R. Changes in the phenolic composition of grape berries during ripening in relation to vineyard nitrogen and potassium fertilisation rates. J. Sci. Food Agric. 2004, 84, 623-630. [CrossRef]

2. Schreiner, R.P.; Scagel, C.F. Nutrient uptake and distribution in a mature 'Pinot Noir' vineyard. HortScience 2006, 41, 336-345. [CrossRef]

3. Schreiner, R.P. Nutrient uptake and distribution in young Pinot noir grapevines over two seasons. Am. J. Enol. Vitic. 2016, 67, 436-448. [CrossRef]

4. Thiebeau, P.; Herre, C.; Doledec, A.-F.; Perraud, A.; Panigaï, L.; Mary, B.; Nicolardot, B. Incidence du mode de couverture du sol sur la fourniture en azote des sols de vigne en Champagne. J. Intern. Sci. Vigne Vin 2005, 39, 163-177. 
5. Bell, S.-J.; Henschke, P.A. Implications of nitrogen nutrition for grapes, fermentation and wine. Aust. J. Grape Wine Res. 2005, 11, 242-295. [CrossRef]

6. Lacroux, F.; Trégoat, O.; van Leeuwen, C.; Pons, A.; Tominaga, T.; Lavigne-Cruege, V.; Dubourdieu, D. Effect of foliar nitrogen and sulphur application on aromatic expression of Vitis vinifera L. cv. Sauvignon blanc. Oeno One 2008, 42, 125-132. [CrossRef]

7. Keller, M.; Arnink, K.J.; Hrazdina, G. Interaction of nitrogen availability during bloom and light intensity during veraison. I. Effects on grapevine growth, fruit development, and ripening. Am. J. Enol. Vitic. 1998, 49, 333-340.

8. Spayd, S.; Wample, R.; Evans, R.; Stevens, R.; Seymour, B.; Nagel, C. Nitrogen fertilization of white Riesling grapes in Washington. Must and wine composition. Am. J. Enol. Vitic. 1994, 45, 34-41.

9. Delas, J.; Molot, C.; Soyer, J.P. Effects of nitrogen fertilization and grafting on the yield and quality of the crop of Vitis vinifera cv. Merlot. In Proceedings of the International Symposium on Nitrogen in Grapes and Wine, Seattle, WA, USA, 18-19 June 1991; Rantz, J.M., Ed.; American Society for Enology and Viticulture: Davis, CA, USA, 1991; pp. 242-248.

10. Sulas, L.; Mercenaro, L.; Campesi, G.; Nieddu, G. Different cover crops affect nitrogen fluxes in Mediterranean vineyard. Agron. J. 2017, 109, 2579-2585. [CrossRef]

11. Shaahan, M.M.; El-Sayed, A.A.; Abou El-Nour, E.A.A. Predicting nitrogen, magnesium and iron nutritional status in some perennial crops using a portable chlorophyll meter. Sci. Hortic. 1999, 82, 339-348. [CrossRef]

12. Rustioni, L.; Grossi, D.; Brancadoro, L.; Failla, O. Iron, magnesium, nitrogen and potassium deficiency symptom discrimination by reflectance spectroscopy in grapevine leaves. Sci. Hortic. 2018, 241, 152-159. [CrossRef]

13. Vrignon-Brenas, S.; Aurélie, M.; Romain, L.; Shiva, G.; Alana, F.; Myriam, D.; Rolland, G.; Pellegrino, A. Gradual responses of grapevine yield components and carbon status to nitrogen supply. OENO One 2019, 53, 289-306. [CrossRef]

14. Daane, K.M.; Almeida, R.P.P.; Bell, V.A.; Walker, J.T.S.; Botton, M.; Fallahzadeh, M.; Mani, M.; Miano, J.L.; Sforza, R.; Walton, V.M.; et al. Biology and management of mealybugs in vineyards. In Arthropod Management in Vineyards: Pests, Approaches, and Future Directions; Bostanian, N., Vincent, C., Isaacs, R., Eds.; Springer: Dordrecht, Germany, 2012; pp. $271-307$.

15. Chiotta, M.L.; Ponsone, M.L.; Torres, A.M.; Combina, M.; Chulze, S.N. Influence of Planococcus ficus on Aspergillus section Nigri and ochratoxin A incidence in vineyards from Argentina. Lett. Appl. Microbiol. 2010, 51, 212-218. [CrossRef] [PubMed]

16. Bordeu, E.; Troncoso, D.O.; Zaviezo, T. Influence of mealybug (Pseudococcus spp.)-infested bunches on wine quality in Carmenere and Chardonnay grapes. Int. J. Food Sci. Technol. 2012, 47, 232-239. [CrossRef]

17. Cocco, A.; Lentini, A.; Serra, G. Mating disruption of Planococcus ficus (Hemiptera: Pseudococcidae) in vineyards using reservoir pheromone dispensers. J. Insect Sci. 2014, 14, 144. [CrossRef] [PubMed]

18. Cocco, A.; Muscas, E.; Mura, A.; Iodice, A.; Savino, F.; Lentini, A. Influence of mating disruption on the reproductive biology of the vine mealybug, Planococcus ficus (Hemiptera: Pseudococcidae), under field conditions. Pest Manag. Sci. 2018, 74, $2806-2816$. [CrossRef] [PubMed]

19. Marras, P.M.; Cocco, A.; Muscas, E.; Lentini, A. Laboratory evaluation of the suitability of vine mealybug, Planococcus ficus, as a host for Leptomastix dactylopii. Biol. Control 2016, 95, 57-65. [CrossRef]

20. Lucchi, A.; Benelli, G. Towards pesticide-free farming? Sharing needs and knowledge promotes Integrated Pest Management. Environ. Sci. Pollut. Res. 2018, 14, 13439-13445. [CrossRef]

21. European Union. Commission implementing regulation (EU) 2018/783. Off. J. Eur. Union L 2018, 132, 31-34.

22. European Union. Commission implementing regulation (EU) 2018/785. Off. J. Eur. Union L 2018, 132, 40-44.

23. European Union. Commission implementing regulation (EU) 2020/17. Off. J. Eur. Union L 2020, 7, 11-13.

24. European Union. Commission implementing regulation (EU) 2020/18. Off. J. Eur. Union L 2020, 7, 14-16.

25. Goodhue, R.; Mace, K.; Rudder, J.; Tolhurst, T.; Tregeagle, D.; Wei, H.; Grafton-Cardwell, B.; Grettenberger, I.; Wilson, H.; Van Steenwyk, R.; et al. Economic and Pest Management Evaluation of the Withdrawal of Chlorpyrifos: Six Major California Commodities. Available online: https://www.cdfa.ca.gov/files/pdf/ChlorpyrifosReport.pdf (accessed on 10 May 2020).

26. Fernandes de Oliveira, A.; Serra, S.; Ligios, V.; Satta, D.; Nieddu, G. Assessing the effects of vineyard soil management on downy and powdery mildew development. Horticulturae 2021, 7, 209. [CrossRef]

27. Cocco, A.; Marras, M.P.; Muscas, E.; Mura, A.; Lentini, A. Variation of life-history parameters of Planococcus ficus (Hemiptera: Pseudococcidae) in response to grapevine nitrogen fertilization. J. Appl. Entomol. 2015, 139, 519-528. [CrossRef]

28. Muscas, E.; Cocco, A.; Mercenaro, L.; Cabras, M.; Lentini, A.; Porqueddu, C.; Nieddu, G. Effects of vineyard floor cover crops on grapevine vigor, yield, and fruit quality, and the development of the vine mealybug under a Mediterranean climate. Agric. Ecosyst. Environ. 2017, 237, 203-212. [CrossRef]

29. Walton, V.M.; Pringle, K.L. Vine mealybug, Planococcus ficus(Sign.) (Hemiptera: Pseudococcidae), a key pest in South Africanvineyards. A review. S. Afr. J. Enol. Vitic. 2004, 25, 54-62.

30. Pavlović, M.; Fantov, T.; Dević, S.; Marcelić, Š.; Franin, K.; Kos, T. The effectiveness of various measures for suppression of scale insect Planococcus ficus (Signoret) (Hemiptera: Coccoidea) on grapevine (Vitis vinifera L.) variety "Chardonnay" in the locality of Baštica, Zadar's county hinterland. In Proceedings of the XV International Symposium on Scale Insect Studies, Zagreb, Croatia, 17-20 June 2019; p. 72. 
31. Pavan, F.; Cargnus, E.; Kiaeianmoosavi, S.; Bigot, G.; Tacoli, F.; Zandigiacomo, P. Bunch-zone leaf removal of grapevines to prevent damage by Lobesia botrana and grey mould. Bull. Insectol. 2016, 69, 107-115.

32. Fornasiero, D.; Duso, C.; Pozzebon, A.; Tomasi, D.; Gaiotti, F.; Pavan, F. Effects of irrigation on the seasonal abundance of Empoasca vitis in North-Italian vineyards. J. Econ. Entomol. 2012, 105, 176-185. [CrossRef]

33. Zanettin, G.; Bullo, A.; Pozzebon, A.; Burgio, G.; Duso, C. Influence of vineyard inter-row groundcover vegetation management on arthropod assemblages in the vineyards of North-Eastern Italy. Insects 2021, 12, 349. [CrossRef]

34. Cocco, A.; Pacheco da Silva, V.; Benelli, G.; Botton, M.; Lucchi, A.; Lentini, A. Sustainable management of the vine mealybug in organic vineyards. J. Pest Sci. 2021, 94, 153-185. [CrossRef]

35. Mercenaro, L.; Nieddu, G.; Pulina, P.; Porqueddu, C. Sustainable management of an intercropped Mediterranean vineyard. Agric. Ecosyst. Environ. 2014, 192, 95-104. [CrossRef]

36. Williams, D.W.; Andris, H.L.; Beede, R.H.; Luvisi, D.A.; Norton, M.V.K.; Williams, L.E. Validation of a model for the growth and development of the Thompson Seedless grapevine. II. Phenology. Am. J. Enol. Vitic. 1985, 36, 283-289.

37. Walton, V.M.; Pringle, K.L. Developmental biology of vine mealybug, Planococcus ficus (Signoret) (Homoptera: Pseudococcidae), and its parasitoid Coccidoxenoides perminutus (Timberlake) (Hymenoptera: Encyrtidae). Afr. Entomol. 2005, 13, $143-147$.

38. Porro, D.; Dorigatti, C.; Stefanini, M.; Ceschini, A. Use of SPAD meter in diagnosis of nutritional status in apple and grapevine. Acta Hort. 2001, 564, 243-252. [CrossRef]

39. Di Stefano, R.; Cravero, M.C. The grape phenolic determination. Riv. Vitic. Enol. 1991, 49, 37-45.

40. Cocco, A.; Mura, A.; Muscas, E.; Lentini, A. Comparative development and reproduction of Planococcus ficus and Planococcus citri (Hemiptera: Pseudococcidae) on grapevine under field conditions. Agric. For. Entomol. 2018, 20, 104-112. [CrossRef]

41. Brunetto, G.; Trentin, G.; Ceretta, C.A.; Girotto, E.; Lorensini, F.; Miotto, A.; Moser, G.R.Z.; de Melo, G.W. Use of the SPAD-502 in estimating nitrogen content in leaves and grape yield in grapevines in soils with different texture. Am. J. Plant Sci. 2012, 3, 1546-1561. [CrossRef]

42. Cerovic, Z.G.; Ghozlen, N.B.; Milhade, C.; Obert, M.; Debuisson, S.; Moigne, M.L. Nondestructive diagnostic test for nitrogen nutrition of grapevine (Vitis vinifera L.) based on dualex leaf-clip measurements in the field. J. Agric. Food Chem. 2015, 63, 3669-3680. [CrossRef]

43. Kliewer, W.M.; Dokoozlian, N.K. Leaf area/crop weight ratios of grapevines: Influence on fruit composition and wine quality. Am. J. Enol. Vitic. 2005, 56, 170-181.

44. Petretto, G.L.; Mercenaro, L.; Urgeghe, P.P.; Fadda, C.; Valentoni, A.; Del Caro, A. Grape and wine composition in Vitis vinifera L. cv. Cannonau explored by GC-MS and sensory analysis. Foods 2021, 10, 101. [CrossRef] [PubMed]

45. Portu, J.; Santamaria, P.; Lopez, R.; Garde-Cerdan, T. Phenolic composition of Tempranillo grapes following foliar application of phenylalanine andurea: A two year study. Sci Hortic. 2017, 219, 191-199. [CrossRef]

46. Hilbert, G.; Soyer, J.P.; Molot, C.; Giraudon, J.; Milin, S.; Gaudillere, J.P. Effects of nitrogen supply on must quality and anthocyanin accumulation in berries of cv. Merlot. Vitis 2003, 42, 69-76.

47. Portu, J.; Lopez-Alfaro, I.; Gomez-Alonso, S.; Lopez, R.; Garde-Cerdan, T. Changes on grape phenolic composition induced by grapevine foliar applications of phenylalanine and urea. Food Chem. 2015, 180, 171-180. [CrossRef] [PubMed]

48. Hogendorp, B.K.; Cloyd, R.A.; Swiader, J.M. Effect of nitrogen fertility on reproduction and development of citrus mealybug, Planococcus citri Risso (Homoptera: Pseudococcidae), feeding on two colors of coleus, Solenostemon scutellarioides L. Codd. Environ. Entomol. 2006, 35, 201-211. [CrossRef]

49. Rhodes, S.A.; Turnbull, M.W.; Chong, J.H. Nitrogen fertilization of host plant influenced the nutritional status and life history of the Madeira mealybug (Hemiptera: Pseudococcidae). Environ. Entomol. 2019, 48, 1129-1137. [CrossRef] [PubMed]

50. Rae, D.J.; Jones, R.E. Influence of host nitrogen levels on development, survival, size and population dynamics of sugarcane mealybug, Saccharicoccus sacchari (Cockerell) (Hemiptera, Pseudococcidae). Aust. J. Zool. 1992, 40, 327-342. [CrossRef]

51. Moon, C.E.; Lewis, B.E.; Murray, L.; Sanderson, S.M. Russian wheat aphid (Homoptera: Aphididae) development, reproduction, and longevity on hydroponically grown wheat with varying nitrogen levels. Environ. Entomol. 1995, 24, 367-371. [CrossRef]

52. Bethke, J.A.; Redak, R.A.; Schuch, U.K. Melon aphid performance on chrysanthemum as mediated by cultivars, and different levels of fertilization and irrigation. Entomol. Exp. Appl. 1998, 88, 41-47. [CrossRef]

53. Walton, V.M.; Daane, K.M.; Bentley, W.J.; Millar, J.G.; Larsen, T.E.; Malakar-Kuenen, R. Pheromone-based mating disruption of Planococcus ficus (Hemiptera: Pseudococcidae) in California vineyards. J. Econ. Entomol. 2006, 99, 1280-1290. [CrossRef]

54. Waterworth, R.A.; Wright, I.M.; Millar, J.G. Reproductive biology of three cosmopolitan mealybug (Hemiptera: Pseudococcidae) species, Pseudococcus longispinus, Pseudococcus viburni, and Planococcus ficus. Ann. Entomol. Soc. Am. 2011, 104, 249-260. [CrossRef]

55. Gonzalez Luna, M.F.; La Rossa, F.R. Parámetros biológicos y poblacionales de Planococcus ficus (Hemiptera: Pseudococcidae) sobre dos cultivares de Vitis vinifera. Rev. Soc. Entomol. Argent. 2016, 75, 45-54.

56. Lentini, A.; Mura, A.; Muscas, E.; Nuvoli, M.T.; Cocco, A. Effects of delayed mating on the reproductive biology of the vine mealybug, Planococcus ficus (Hemiptera: Pseudococcidae). Bull. Entomol. Res. 2018, 108, 263-270. [CrossRef]

57. White, T.C.R. The Inadequate Environment_Nitrogen and the Abundance of Animals; Springer: Berlin/Heidelberg, Germany, 1993; pp. $1-425$. 
58. Bentz, J.A.; Reeves, J., III; Barbosa, P.; Francis, B. Nitrogen fertilizer effect on selection, acceptance, and suitability of Euphorbia pulcherrima (Euphorbiaceae) as a host plant to Bemisia tabaci (Homoptera: Aleyrodidae). Environ. Entomol. 1995, $24,40-45$. [CrossRef]

59. Mgocheki, N.; Addison, P. Spatial distribution of ants (Hymenoptera: Formicidae), vine mealybugs and mealybug parasitoids in vineyards. J. Appl. Entomol. 2010, 134, 285-295. [CrossRef]

60. Dalla Montà, L.; Duso, C.; Malagnini, V. Current status of scale insects (Hemiptera: Coccoidea) in the Italian vineyards. Boll. Zool. Agr. Bachic. 2001, 33, 343-350.

61. Oliveira, M.D.; Barbosa, P.R.; Silva-Torres, C.S.; Silva, R.R.; Barros, E.M.; Torres, J.B. Reproductive performance of striped mealybug Ferrisia virgata Cockerell (Hemiptera: Pseudococcidae) on water-stressed cotton plants subjected to nitrogen fertilization. Arthropod-Plant Interact. 2014, 8, 461-468. [CrossRef] 